\title{
Morsels on the Tongue: Evidence of a Pre-Christian Matriarchy in Russian Fairy Tales
}

\author{
IRENEUSZ SZARYCZ \\ Department of Germanic and Slavic Languages and Literatures, Faculty of Arts, \\ University of Waterloo, 200 University Avenue West, Waterloo, Ontario, Canada, N2L 3G1 \\ E-mail: iszarycz@watarts.uwaterloo.ca
}

\begin{abstract}
The Russian fairy tale has endured centuries of evolution. It was part of an oral tradition and as such, none of its details were static. A single story was told by generations of storytellers over a period of centuries. In this way, the tale is layered with beliefs and customs from many periods reaching far back to the pre-Christian, matriarchal times. While weakness and submissiveness are the preferred qualities of Russian folk heroines, many tales portray women of strength. The introduction of Christianity to 10th-century Russia extinguished there a strong matriarchal tradition. Matriarchal cultures are traditionally linked with mysticism and magic. Given the hypothesis of an early Russian matriarchy, the paper traces magical figures like Baba Yaga and her sisters back to a time when there was no need to portray them as evil. It is only after the priests come that she was cast out and labeled evil. The Russian fairy tale may appear to be vague, repetitious and hard on women, yet when these qualities are added together a magical transformation occurs that brings out lively and simplistically beautiful images that give the tales that special Russian flavour.
\end{abstract}

Keywords: Russian Folklore, Paganism, Christianity, Women's Issues

The fairy tale is indeed a unique type of genre. It has endured centuries of evolution, if not longer, and had continued to maintain that charming, mystical quality that captures the fantastical, hopeful, and child-like side of whomever it entertains. Fairy tales re-affirm our hope and belief that anything is possible; that nothing is beyond our grasp and if we believe and try virtuously, we can attain our dreams. Many fairy tales include a strong moralistic flavour, attempting to instill virtuous qualities into children by method of example and fear as well as entertaining them. A fairy tale is only as entertaining and effective as its audience's willingness to temporarily suspend its disbelief. This accounts for the greater disassociation from the genre as one progresses into questioning, disbelief, and mistrust which accompanies adulthood. However, fairy tales can still be entertaining for this older crowd, in that the story becomes a riddle, with the audience searching for connection/recognition of real people, places and events as well as trying to unearth a deeper, perhaps insightful meaning, lying latent in the tale, that may have relevance in their lives.

Fairy tales, while fulfilling these qualities, cannot, however, effectively be observed or studied collectively. There is an evident universality of themes common amongst fairy tales of different cultures, where individual flavours and tones give each country's tales their own particular charm and identifiable characteristics. There are three critical approaches to fairy tales, namely: human- 
istic, anthropological, and psychological-psychoanalitic. For the purpose of this paper the humanistic approach is employed which is understandably more appropriate than the remaining two for a scholar of literature and language. The fairy tales selected for this paper will be studied as "oral literature" and assessed as a literary critic would assess a novel, a play or a poem. Therefore, relying on the available extrinsic (anthropological and archaeological) evidence found in Joanna Hubbs' book Mother Russia. The Feminine Myth in Russian Culture, ${ }^{1}$ an attempt will be made to point out the intrinsic evidence available within the fairy tales which came to us in a written form recorded without any changes by A. N. Afanas'ev in the nineteenth century. ${ }^{2}$ In his article entitled "Folklore and Anthropology" W. R. Bascom writes:

Anthropologists have come to the conclusion that the search for ultimate origins... is a hopeless one where historical documents and archaeological evidence are lacking. In folklore, where archaeology can be of almost no help at all, and where documentation does not yield the answers directly, attempts to reconstruct history on an even more restricted scale can yield results only in terms of probability rather than proven fact... The anthropologist, to speak frankly, feels that his colleagues in folklore are often so preoccupied with the problems of origin and historical reconstruction that they overlook problems of equal or greater significance to which one can hope to find satisfactory answers. He looks to them for guidance in literary analysis of folklore... ${ }^{3}$

Although there are numerous studies which try to trace the origins of Russian fairy tales, to analyse their characters and structure, thus pointing out their many themes and motifs, ${ }^{4}$ there is no single work, however, that deals in depth with the place of women and their role in the ever changing world of fairy tales after the introduction of Christianity in Russia.

\footnotetext{
${ }^{1}$ Joanna HubBs, Mother Russia. The Feminine Myth in Russian Culture, Bloomington: Indiana University Press, 1988.

${ }^{2}$ Russian Fairy Tales, ed. Aleksandr Afanas'ev, trans. Norbert Guterman. New York: Pantheon, 1974. In Russian: Narodnye russkie skazki, 3 vols. Moscow: Nauka, 1958.

${ }^{3}$ W. R. BASCOM, "Folklore and Anthropology," in The Study of Folklore, ed. A. Dundes (Englewood Cliffs, N.J., 1965) 31.

${ }^{4}$ For example, see the following selected works: Vladimir PROPP, Istoričeskie korni volshebnoi skazki. Leningrad: Izdatel'stvo Leningradskogo Universiteta, 1946. Morfologiia skazki. Leningrad: Izdatelstvo Leningradskogo Universiteta, 1928; E. M. MELETINSKII, Geroi volshebnoi skazki: Proiskhozhdenie obraza. Moscow: Akademiia Nauk, 1958; Maria-Gabrielle Wosien, The Russian Folk-Tale: Some Structural and Thematic Aspects. München: Verlag Otto Sagner, 1969; Maria Kravchenko, The World of Russian Fairy Tale. New York: Peter Lang, 1987; E. V. PoMERANTSEVA, Mifologicheskie personazhi v russkom fol'klore. Moscow, 1975; V. N. Toporov, "Khettskaia Salgusi i slavianskaia Baba-Yaga." Akademiia nauk SSSR, Institut slavianovedeniia, kratkie soobshcheniia, vol. 38, 1963, 14-32; V. V. IVANOV and V. N. TOPOROV, Issledovaniia v oblasti slavianskikh drevnostei. Moscow: Nauka, 1974; B. A. RYBAKOv, "Drevnie elementy v russkom narodnom tvorchestve." Sovetskaia etnografiia, no. 1, 1948, 90-106; F. J. OINAS and S. Soudakoff, eds. The Study of Russian Folklore. The Hague, 1975; D. P. Costello and I. P. Foote, Russian Folk Literature. Oxford: Clarendon Press, 1967; P. MARANDA, ed. Soviet Structural Folkloristics. Vol. 1, The Hague: Mouton, 1974; N. V. Novikov, Obrazy vostochnoslavianskoi skazki. Leningrad: Nauka, 1974; Y. M. SoKOlov, Russian Folklore, trans. Catherine Ruth Smith, Hatboro, 1966.
} 
One of the characteristic traits of Russian folktales is that they are peopled by types: the slow-witted son, the brave warrior, the honest peasant. Perhaps unique to these stories, however, and to their credit, is their surprisingly egalitarian treatment of these types. In the Russian fairy tale, happy endings are open to all. The foolish peasant gets the kingdom and the girl at least as often as does the handsome prince.

There is, however, a striking hitch in the democratic world of Russian folklore. This is that someone always gets the girl, while she herself never gets, is only ever gotten. Woman here is a property to be acquired, an enemy to overcome, a cross to be borne or a lawbreaker to be punished. The only possible happy ending for Russian heroine is that she can stand by her husband while he gets what he wants. What, if anything, the woman wants in these stories is invariably foolish, and she is punished for it.

This is, in fact, the gist of one of the stories from Aleksandr Afanas'ev's collection of Russian tales entitled "The Mayoress" (Головиха). An ambitious village woman asks her husband to have her elected as mayor. He knows that she is weak and prone to sin, and, therefore unable to fulfill the duties of that office, but, to teach her a lesson, he complies. As expected, she is dishonest and incompetent in the performance of her job and, therefore, receives a cruel beating. The story ends with the wife pleading to be removed from office and settling down to obey her husband.

"The Mayoress" is only one of a school of cautionary tales for wives which appear in Afanas'ev's collection. "The Wondrous Wonder, The Marvelous Marvel" [13] (Диво дивное, чудо чудное), "The Bad Wife" [56] (Сказки о злой жене), "The Taming of the Shrew" [161] (Народные анекдоты), and "The Indiscreet Wife" [226] (Жена-доказчица) are among the many others which features wives beaten or killed by their husbands for their assorted crimes. In order half of these stories, the husbands are rewarded as a consequence of having abused their wives.

While it may be tempting for the defender of Russian folklore to frame these stories as morality tales rather than as examples of misogyny, it is not very plausible against the background of such stories as "The Feather of Finist, the Bright Falcon" [580] (Пёрышко Финиста ясна сокола) and "Prince Ivan, the Firebird, and the Grey Wolf” [612] (Сказка об Иване-царевиче, жар птице и о сером волке) where male protagonists are rewarded for adultery and theft. In the world of Russian folklore, women who gossip are savagely beaten, while men who steal are showered with gifts.

To be fair, a great many of these stories describe punishment or death for evil men, but here is the crux. In evaluating the virtue of a character, Russian

\footnotetext{
5 "The Mayoress", Russian Fairy Tales, 141. Hereafter, the location of all stories cited from this collection will be indicated by square brackets containing a page number, following the title. The original titles in Russian are also provided.
} 
folklorists have traditionally used two standards. Women may be either perfect or imperfect, while men be either evil or not evil. The imperfect woman though she may have some good in her - receives the same treatment as the evil man. And the rewards received by the man who is merely "not evil" inevitably surpass those of even a perfect woman.

This is understandable, given that, in the ideal of womanly perfection presented in the stories, the qualities of self-abnegation and humility figure prominently. The Russian heroine's goal is to help her husband. In "The Wise Wife" [521] (Мудрая жена) and "Go I Know Not Whither, Bring Back I Know Not What" [504] (Поди туда - не знаю куда, принеси то - не знаю что), the virtuous and powerful heroines deny even their own identities, transforming themselves into a stone and bird, respectively, in order to ensure their own faithfulness during their husbands' absence.

Both women are also able to magically help their husbands by receiving beatings at their own request. In the first story, the hero transforms his wife into a faithful rock, and later back into a woman, by striking her three times with three twigs. The protagonist of the second story turns the dove into beautiful wife by beating her with the back of his hand. The message here is the same as in "The Taming of the Shrew, "the same message promulgated by the Orthodox Church in the 16th-century work entitled Domostroj ${ }^{6}$ (Домострой — On the Ordering of a Household): a man makes a woman truly his own by beating her. These heroines - as paradigms of feminine virtue — understand and desire this.

That the male figures in these stories prosper, not only through abusing their wives, but also by murdering two old ploughmen (in "The Wise Wife") and swindling three merchants (in "Go I Know Not Whither...") reflects the entirely different set of qualities portrayed as desirable in a man. The male paradigm is bold, ambitious and frequently ruthless. Boastfulness, rather than humility, is the preferred male quality.

Consider the case of the title character in "Ivan the Simpleton" [142] (Иванушка дурачок). Ivan's only virtue is his boastfulness, yet this is enough for him to win the loyalty of the two heroes - Il'ja Muromec and Fedor Lyžnikov. They defeat an entire army for him, thereby allowing him to marry that kingdom's princess and live in ease. In "The Dead Body" [118] (Мёртвое тело) Ivan the Fool kills his mother, then lies about it, implicating an official. For this, he receives three hundred rubles and comes "home to his father and brothers, and

\footnotetext{
${ }^{6}$ Domostroi (from Greek oikonomia, beginning of the 16th c. in Novgorod) - according to Marc Slonim: was in the 19th century always cited as an example of Russian obscurantism and even barbarism, which is not quite correct; rather it is both a book of morality and an anthology of the household arts; it contains the norms of social, domestic, and economic life, as conceived by a representative of the Russian petite bourgeoisie; it also advises its readers on the relations of the sexes and points out the way to improving the family atmosphere through "moderate wife-beating!" Revised in the 16th c. by priest Silvester a personal advisor and confessor of Ivan Grozny (the Terrible).
} 
they all began to live happily together". "The Jester" [151] (Шут) lies, cheats, murders, and thrashes his obedient wife, and for all this ingenuity is rewarded nine hundred rubles.

While weakness and submissiveness are the preferred qualities of Russian folk heroines, many tales portray women of strength. The three main species of strong women are comprised of Baba Yaga-type figures and wise maidens (both usually have supernatural powers), and warrior maidens - palenicy or bogatyrki. However, even in these characters, strength is seen less as a womanly virtue than as dangerous - if useful - force which must be subdued.

In the many tales featuring Baba Yaga or the common variant of three successive Baba Yaga sisters of ascending age, the Baba Yagas most often assist the hero or heroine in his or her quest. However, Baba Yaga is invariably portrayed as an evil figure. The two or three tales representing Baba Yaga as cruel and cannibalistic are inconsistent with her usual performance. They seem less a description of Baba Yaga's original incarnation than a later attempt to brand a powerful female character evil and, therefore, unacceptable.

This same need to render a strong woman man-agreeable may be seen in the portrayal of the wise maiden. This figure is beautiful and intelligent, and usually has a knowledge of magic, most often passed down to her by a community of female forebears. However, the wise maiden is prevented by the storyteller from being a threat to male superiority through her obedience to her husband. As discussed earlier, this positive character denies herself and focuses her powers on fulfilling the wishes of her husband. That this often includes using her powers against her own father when her husband desires it (cf. "The Sea King and Vasilisa the Wise" [427] (Морской царь и Василиса Премудрая) betrays the folklorist's consciousness of the, at least potential, threat that the strong woman poses towards a patriarchal society.

This threat is felt so strongly that the wise maiden's power is mitigated still further by youth. She is usually the youngest of several daughters... a mere girl who knows magic presumably presenting a lesser danger than a mature woman with the same knowledge. After satisfying her husband's wishes, the wise maiden settles down to "chew bread" with him, no further mention being made of her supernatural abilities. Apparently, marriage has subdued her. The older women in her line are usually variations on the Baba Yaga type, without husbands or lovers. Women in Russian fairy tales only continue to wield magical powers into middle age if they remain unmarried. And they, of course, are ugly and evil.

Russian folklore's final type of strong woman, the warrior maiden, is less common than her sisters. According to Russian feminist activist Tatyana Mamonova "The pre-Christian epics, with their giant bogatyrs were equally peopled with folk heroines, the palenitsas - mighty women bogatyrkas"? However, few of these characters survive in the folk tales now extant.

\footnotetext{
${ }^{7}$ Tatyana Mamonova, "Matriarchal Roots in Russian Folklore", trans. Rebecca Park, Russian Women's Studies: Essays on Sexism in Soviet Culture (Oxford: Pergamon, 1989) 3.
} 
In "The Feather of Finist, the Bright Falcon", the heroine, the (significantly) nameless "lovely maiden", embarks upon a hard quest during which she must wear out three pairs of iron shoes, break three cast-iron staves, and gnaw away three stone wafers. After great trials, she is ultimately successful, but she is hardly a bogatyrka.

Closer to the pre-Christian palenitsa figure is the title character in "Marya Morevna" [553] (Марья Моревна). Prince Ivan comes upon a field strewn with the slain bodies of a great army and discovers their conqueror to be Marya Morevna, the beautiful queen. He meets her, they fall in love and are married. Shortly after the two have taken up residence in Morevna's castle, the queen goes off to wage war, warning her husband not to open the door to a particular closet in her absence. Needless of her warnings, Ivan opens the closet and finds inside Koshchei the Deathless. He is bound by twelve chains, Morevna's prisoner.

Ivan unwittingly releases him, and suddenly the story changes gear. Morevna, formerly a great warrior, is easily captured by Koshchei and held by him, helpless as a kitten. The rest of the story is purely patriarchal as Morevna - now merely beautiful - is rescued by husband and brothers-in-law. The two halves of the story are so disjointed as to have been obviously invented at different times, by different story-tellers. A Russian feminist Tatyana Mamonova rightly points out that "Examined logically, this story's characters and events suggest that in the original, or earlier, versions, Marya herself defeated Koshchei the Immortal". Again, later storytellers were uncomfortable with the strong woman character; so reduced her to someone less threatening.

A problem becomes obvious: Why invent strong women only to weaken them? Why give them powers at all if the powers are to be diminished? Here, it is important to note that the Russian folk tale was part of an oral - not written - tradition. As such, none of the stories' details were static. A single story was told by generations of storytellers over a period of centuries. As each teller added his own details, the stories evolved. In this way, the tales are layered with beliefs and customs from many periods.

The best explanation, then, for the nature of strong woman's portrayal in the stories is that, at some point, the tales' creators were comfortable with the notion of a powerful female and invented characters which reflected this; then, a dramatic change in society's perception of sex-roles led a new generation of fabulists to cripple these characters - with ugliness or weakness of youth.

The introduction of Christianity to 10th-century Russia is the most obvious reason for this change. Legend speaks of a time before Christianity when Rus' was predominantly matriarchal. ${ }^{9}$ This matriarchy could not live alongside the patriarchal Christian Church. Christianity's victory in Russia was the matriarchy's defeat.

${ }^{8}$ MAMONOVA 6.

${ }^{9}$ Mamonova 3.

Studia Slavica Hung. 46, 2001 
The Judeo-Christian religions have been among the most oppressive to women. According to the Church, woman was created of man, for man - to assuage his loneliness. Woman is dependent upon man, then, and subordinate to him. She was created to serve man, and even for this was too weak. Eve Adam's rib - was the cause of the expulsion from Eden and, hence, of all human suffering. For this, all of her daughters are condemned. The God of Christianity is a man, His angels - men, His only-begotten - a son, His son's disciples - men, His priests - men. God's women are wives, servants, and seductresses; they are deceitful and weak - Delilah betrayed Samson; Lot's wife could not betray the morass of sin from which God had tried to save her. Only Mary was truly good - Mary, whose importance lay in the fact that she ushered into the world yet another man more important than herself.

Not even this single example of female goodness could help salvage the vestiges of matriarchy in the newly-Christianized Rus', for the Byzantine Church lacked the strong Marian focus of its Roman counterpart. The Church that came to Russia was not the Church of the Blessed Virgin, but the Church that five centuries earlier had found strong women so repulsive that monks tore the noted Greek woman philosopher, Hypatia, limb from limb, burned all of her works and scattered her disciples. ${ }^{10}$ The Church that came to Russia was the same that, in the 16th century, set down as the guide for domestic life the Domostroi, a book that recommends improving the family environment through "moderate wife beating." (Small wonder that husbands in post-Christian tales are rewarded for wife abuse when the Church has blessed it.) If we assume this hypothesis - that the introduction to Russia of Christianity extinguished there a strong matriarchal tradition - then it is easy to understand the inconsistencies within the portrayals of female characters in Russian folklore.

Matriarchal cultures are traditionally linked with mysticism and magic. Given the hypothesis of an early Russian matriarchy, we can trace magical figures like Baba Yaga and her sisters back to a time when there was no need to portray them as evil. Baba Yaga need not be evil. She is, rather, old, powerful and wise: ... old, because she has not been subjugated into the role of mere childbearer, has not spent her youth producing one after another heir for her husband,

\footnotetext{
${ }^{10}$ Hypatia (a philosopher, b. c. 370 A.D. in Alexandria, Egypt - d. 415 Alexandria). The first notable woman in mathematics. The daughter of Theon, also a mathematician and philosopher, she became the recognized head of the Neoplatonist school of philosophy at Alexandria, and her eloquence, rare modesty, and beauty, combined with her remarkable intellectual gifts, attracted a large number of pupils. Hypatia symbolized learning and science, which at that time in Western history was largely identified by the early Christians with paganism. As such, she was a focal point in the tension and riots between Christians and non-Christians that more than once racked Alexandria. Shortly after the accession of Cyril to the patriarchate of Alexandria in 412, Hypatia was barbarously murdered by the monks and a fanatical mob of Cyril's Christian followers, supposedly because of her intimacy with the city's pagan prefect. Her philosophy was more scholarly and scientific in its interest and less mystical and pagan than the Athenian school.

${ }^{11}$ Quoted in Marc SLONIM, The Epic of Russian Literature (New York-Oxford, 1964) 15.
} 
only to eventually die in childbirth (the fate of vast majority of women in preindustrial, patriarchal societies); powerful and wise, because she has learned the magical secrets locket within the earth, because she has been nurtured and taught these secrets by a community of wise women, because the guardians of patriarchal faith have not yet tried to destroy this knowledge, to disperse the community from whence the wisdom springs. Why Baba Yaga so often offers aid to those who seek her out is no longer any mystery, on this account. She offers aid because she is part of a pagan community and functions within that community as a sort of shaman. It is her role to help those in need. It is only after the priests come that she is ostracized by the community, cast out and labeled evil, with later stories describing her cruelty offering a warning to those who would seek her. The warning is this: Beware the pagan woman; what you need (want) is a Christian man. Perhaps before the priests, Baba Yaga's daughters, the wise maidens, were able to blossom into wise middle-aged women, wise mothers and wise grandmothers, rather than closing their books of magic as soon as they opened their legs for a man. Perhaps before the priests, Marya Morevna did not have to choose between husband and strength ... perhaps herself put Koshchei soundly back in his place. (Perhaps she gave Prince Ivan a sound thrashing for his disobedience, much as her descendants would one day receive for the same crime in Domostroi - inspired domestic tales). Perhaps before the priests, Russian men had sufficient respect for their mothers and wives not to lay a finger on them for any amount of money. Perhaps their mothers and wives earned this respect more easily, not having been reduced to gossipy shrews by a Church that gave them nothing. However, the priests did come eventually and soon obliterated all memory of the matriarchy which had flourished before them, which now survives only in the tiny morsels which remained on the tongues of the storytellers.

"The Sorceress" [567] (from a collection of stories about witches "Рассказы о ведьмах") may be read as an account of this conquest. The story begins with the court priest's ten-year-old son discovering the king's daughter in the practice of sorcery. He soon tells everyone. Suddenly, the princess falls ill and dies, her last request being that the priest's son should read the Psalter over her three nights successively. This he does. Each night, she rises from the dead and attempts to avenge herself upon him for telling about her practices. He emerges safely, thanks to the magic taught him by his teacher, an old woman. Finally, the boy reveals to the king the terrors wrought by his daughter. The king has a stake driven through her heart and her body buried. The young boy he rewards with money and land. It is almost impossible to read this story without envisioning the priest's son as the Church, newly arrived in Rus' but already influential. The king himself is Rus'; he has ties with the Church, but still harbours a pagan element within his kingdom.

The Russian matriarchy consists of two generations - the old woman and the young princess. The latter is still immature, stays within the palace, knows 
the magic of her ancestors but still only uses it for her own amusement. (Or is she practicing? Rehearsing to be a contributing member of the matriarchal community?). The older woman has ceased to play with her power; instead, she teaches. Perhaps she too is a pre-Christian shamanistic figure. She does not live in the palace, but on her own. In Afanas'ev's collection, Baba Yaga and the other magical old women lived apart from the kingdom and had to be sought out for aid, much as the priest's son here goes to the old woman for his lessons.

The Church (the boy) is afraid of the matriarchy, cannot exist alongside it. But he is clever. Marvelously assimilative as the Christian Church is, he divides the matriarchy, learning from the old woman, who will soon die anyway, while spreading fear of the young princess. She, after all, is the real threat, since she can yet produce young - and induct them into her tradition.

The object of fear now, the weak, young element of the matriarchy no longer has the community so essential to its existence. It is weakened. Thus ensues a battle pitting the pagan matriarchy against the Christian patriarchy. The Church has become too powerful and the woman perishes. The Church again tells of the ugliness, the terrors (terrors which include, significantly, the illusion of a burning Church) of this matriarchy which might yet revive.

So King Rus' - who has never seen anything terrible about this matriarchy, whose only evidence against her is the word of the young Church - forgets that she is his daughter (his mother, his wife) and himself ensures that she will never again rise. And the Church, with the pagan threat now destroyed, receives riches and Russian land. The end of the matriarchy marks the entrenchment of Christianity in Russia.

Russian fairy tales have that peculiar flavour that can only be described as "Russian". The whole culture and history of the people create a style of fairy tales that had beheld centuries of influences and hardships but has still endured and prevailed with their own individual characteristics, maintaining a strong historical tie to their origins. The Russian fairy tale may appear to be vague, repetitious and hard on women, yet when these qualities are added together and mixed with a Russian spoon, a magical transformation occurs that brings out humorous, lively and simplistically beautiful images that give the tales their special flavour.

\section{Works Consulted}

AtKInson, Dorothy, Alexander Dallin, and Gail Warshofsky Lapidus, eds. Women in Russia. Stanford: Stanford University Press, 1977.

BASCOM, W. R., "Folklore and Anthropology," in The Study of Folklore, ed. A. Dundes. Englewood Cliffs, N. J., 1965.

HubBS, Joanna. Mother Russia. The Feminine Myth in Russian Culture, Bloomington: Indiana University Press, 1988.

KIng, Ursula, ed. Women in the World's Religions. Past and Present. New York: Paragon House, 1987.

Kravchenko, Maria . The World of Russian Fairy Tale. New York: Peter Lang, 1987. 
Olson, Carl, ed. The Book of the Goddess. Past and Present. An Introduction to Her Religion New York: Crossroad, 1983.

Olson, Carl, ed. The Book of the Goddess: Past and Present. New York: Crossroad, 1987.

SHARma, Arvind, ed. Introduction by Katherine K. Young. Women in World Religion. Albany: State University of New York Press, 1987.

Shirley, Eugene B. Jr., and Michael Rowe, eds. Forward by Richard Shifter. Candle in the Wind. Religion in the Soviet Union. Washington, D.C.: Ethics and Public Policy Center, 1989.

Wosien, Maria-Gabrielle. The Russian Folk-Tale: Some Structural and Thematic Aspects. München: Verlag Otto Sagner, 1969.

Znayenko, Myroslava T. The Gods of the Ancient Slavs. Columbus: Slavica, 1980. 